\title{
Synthesis of fluorapatite-hydroxyapatite nanoparticles and toxicity investigations
}

\author{
This article was published in the following Dove Press journal: \\ International Journal of Nanomedicine \\ 27 January 201 I \\ Number of times this article has been viewed
}

\section{N Montazeri \\ $R$ Jahandideh \\ Esmaeil Biazar}

Department of Chemistry, Islamic Azad University-Tonekabon Branch, Mazandaran, Iran
Correspondence: Esmaeil Biazar Department of Chemistry, Islamic Azad University-Tonekabon Branch, Mazandaran, Iran

Tel +98 I92 427 I I 05

Fax +98 1924274415

Email e.biazar@tonekaboniau.ac.ir
Abstract: In this study, calcium phosphate nanoparticles with two phases, fluorapatite (FA; $\left.\mathrm{Ca}_{10}\left(\mathrm{PO}_{4}\right)_{6} \mathrm{~F}_{2}\right)$ and hydroxyapatite $\left(\mathrm{HA} ; \mathrm{Ca}_{10}\left(\mathrm{PO}_{4}\right)_{6}(\mathrm{OH})_{2}\right)$, were prepared using the solgel method. Ethyl phosphate, hydrated calcium nitrate, and ammonium fluoride were used, respectively, as $\mathrm{P}, \mathrm{Ca}$, and $\mathrm{F}$ precursors with a $\mathrm{Ca}: \mathrm{P}$ ratio of 1:72. Powders obtained from the sol-gel process were studied after they were dried at $80^{\circ} \mathrm{C}$ and heat treated at $550^{\circ} \mathrm{C}$. The degree of crystallinity, particle and crystallite size, powder morphology, chemical structure, and phase analysis were investigated by scanning electron microscopy (SEM), X-ray diffraction (XRD), Fourier transform infrared spectroscopy (FTIR), and Zetasizer experiments. The results of XRD analysis and FTIR showed the presence of hydroxyapatite and fluorapatite phases. The sizes of the crystallites estimated from XRD patterns using the Scherrer equation and the crystallinity of the hydroxyapatite phase were about $20 \mathrm{~nm}$ and $70 \%$, respectively. Transmission electron microscope and SEM images and Zetasizer experiments showed an average size of $100 \mathrm{~nm}$. The in vitro behavior of powder was investigated with mouse fibroblast cells. The results of these experiments indicated that the powders were biocompatibile and would not cause toxic reactions. These compounds could be applied for hard-tissue engineering.

Keywords: fluorapatite, hydroxyapatite, sol-gel, nanoparticles, biocompatibility

\section{Introduction}

Hydroxyapatite $\left(\mathrm{HA} ; \mathrm{Ca}_{10}\left(\mathrm{PO}_{4}\right)_{6}(\mathrm{OH})_{2}\right)$ is a type of calcium phosphate that has extensive application in the healing of bones and teeth, due to its biocompatibility and similar composition to that of natural bone..$^{1-5}$

One of the most common methods for the synthesis of hydroxyapatite and fluorapatite is the sol-gel method. ${ }^{6}$ Synthesis of fluorohydroxyapatite powder by this method is achieved by mixing the raw materials on a molecular scale. In this study, sol-gel processing was used to synthesize the calcium phosphate powders. The advantages of the sol-gel method over other methods are precise control of composition, low processing temperature, and better homogeneity. The required calcination temperature for nanostructured materials that are obtained from this method is low, which prevents phase changes. Other advantages of the sol-gel method in comparison with other methods are high purity, homogeneous composition, and low temperature of synthesis. ${ }^{6,7}$

Pure fluorapatite $\left(\mathrm{FA} ; \mathrm{Ca}_{10}\left(\mathrm{PO}_{4}\right)_{6} \mathrm{~F}_{2}\right)$ has more chemical and structural stability than hydroxyapatite and forms the outer layer of teeth. ${ }^{8-10} \mathrm{~F}$ ions encourage the mineralization and formation of calcium phosphate crystals in the bone formation process. The effect of fluoride ions on the properties of hydroxyapatite can be explained by the investigation of the solid solution of the two phases of fluorapatite and hydroxyapatite. ${ }^{11,12}$ 
The chemical composition factor used to control the bioactivity and feasibility of preparing very fine particles increases hope for the production of suitable bioactive powders for dental tissue applications.

\section{Materials and methods}

In order to prepare the solution, triethyl phosphite (TEP) $\left(\mathrm{C}_{2} \mathrm{H}_{5} \mathrm{O}\right) 3 \mathrm{P}$ (Merck), $\mathrm{NH}_{4} \mathrm{~F}$ (Merck), and $\mathrm{Ca}\left(\mathrm{NO}_{3}\right)_{2.4} \mathrm{H}_{2} \mathrm{O}$ (Merck) in ethanol were used, respectively, as $\mathrm{P}, \mathrm{F}$, and $\mathrm{Ca}$ precursors with a nonstoichiometric $\mathrm{Ca}: \mathrm{P}$ ratio equal to $1: 72$. First, $\mathrm{NH}_{4} \mathrm{~F}$ was added to TEP in ethanol $(\mathrm{P} / \mathrm{F}=6)$ and, in a separate container, calcium nitrate tetrahydrate was dissolved in ethanol. The resulting solutions were vigorously agitated for 24 hours. Subsequently, the solution containing $\mathrm{Ca}$ was added to the solution containing P. The resulting solution was kept at room temperature for 72 hours and then aged at room temperature for a period of 24 hours. The samples were dried at $70^{\circ} \mathrm{C}$ for 3 days and heat treated at $550^{\circ} \mathrm{C}$ for 1 hour. The resultant powders were milled using alumina haven for 20 minutes. Figure 1 shows the process of powder preparation. Chemical properties, phase composition, chemical structure and size, and morphological properties of the particles were studied by X-ray diffraction (XRD) (Siemens and Bruker, Erlangen, Germany), Fourier transform infrared spectroscopy (FTIR) (BoMem Model MB100),

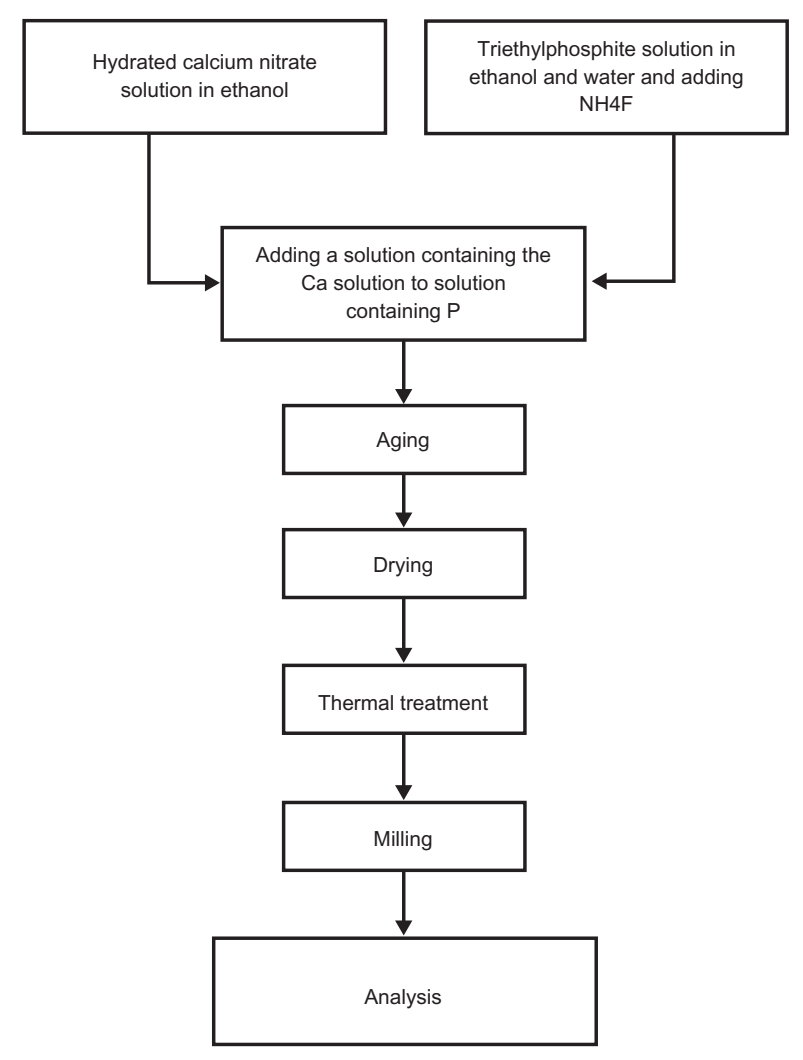

Figure I Powder preparation by sol-gel method.
Zetasizer (3000 HAS; Malvern Instruments Ltd, Malvern, UK), scanning electron microscopy (SEM) (XL30; Philips, Eindhoven, Holland), and transmission electron microscopy (TEM) (CM200FEG; Philips).

For cytotoxicity analysis, fibroblast cell suspension (L929) from mouse tails was prepared according to International Organization for Standardization 10993 standards. The control powders (TCPS) were well cleaned and sterilized by the autoclave method. Individual samples were placed in Petri dishes using a sterilized pincer; $3 \mathrm{cc}$ of the cell suspension was removed by pipette and poured into the control and experimental samples. Thereafter, all of the samples were placed separately in a Memmert incubator at $37^{\circ} \mathrm{C}$ for 24 and 48 hours. The samples in the polystyrene Petri dish were removed from the incubator after 24 and 48 hours and studied using an Eclipse TS-100 photonic microscope (200X; Nikon, Tokyo, Japan).

\section{Results and discussion FTIR analysis}

Figure 2 shows the bands or functional groups of the powders. The apatite structure indicates $560-1610 \mathrm{~cm}^{-1}$ and $1000-1100 \mathrm{~cm}^{-1}$ vibration modes for the PO group. A broad peak indicates $2600-3800 \mathrm{~cm}^{-1}$ related to the $\mathrm{OH}$ group. A small peak between $3536 \mathrm{~cm}^{-1}$ and $3545 \mathrm{~cm}^{-1}$ relates to the $\mathrm{OH}-\mathrm{F}$ bond, which indicates $\mathrm{F}$ ion penetration into the apatite network. The peak $1635 \mathrm{~cm}^{-1}$ relates to the water-bending mode. ${ }^{13}$

Suchanek et al showed an $\mathrm{OH}$ vibration mode of about $630 \mathrm{~cm}^{-1}$ for hydroxyapatite. ${ }^{14}$ This peak is not shown in Figure 2. A small peak in the range $3200-3400 \mathrm{~cm}^{-1}$ relates to the water in the structure. A $3541 \mathrm{~cm}^{-1}$ stretching mode was observed related to the hydroxyl groups. The presence of the hydroxyl group was due to the hydrogen bond of the fluorine ions. This peak confirmed the crystal structure of the flourapatite with hydroxyl groups. These observations for fluorohydroxyapatite powder are due to the hydrogen bond formation between $\mathrm{F}$ and $\mathrm{OH}(\mathrm{F}-\mathrm{OH})$, which indicates substitution $\mathrm{F}$ ions instead of $\mathrm{OH}$ ions in the apatite structure. However, the exact amount of $\mathrm{F}$ ions replaced with $\mathrm{OH}$ ions could not be determined by FTIR analysis. Substitution of different ions in the apatite structure reduces the symmetry and thus causes band absorption in the IR spectrum. A sharp and broad peak between $900 \mathrm{~cm}^{-1}$ and $1100 \mathrm{~cm}^{-1}$ is related to the $\mathrm{PO}_{4}^{3-}$ group. Stretching and bending modes for $\mathrm{PO}_{4}^{3-}$ are showed at $600 \mathrm{~cm}^{-1}, 572-560 \mathrm{~cm}^{-1}$, and $561 \mathrm{~cm}^{-1}$. The band of $1956 \mathrm{~cm}^{-1}$ is related to the $\mathrm{PO}_{4}^{3-}$ group with fluorapatite and hydroxyapatite. The band of $956 \mathrm{~cm}^{-1}$ is related to $\mathrm{PO}_{4}{ }^{3-}$ group with flourapatite and flourohydroxyapatite. Bands of $963 \mathrm{~cm}^{-1}$ and $1500-1400 \mathrm{~cm}^{-1}$ are related to the CO group, which is related to the carbonate ion of hydroxyapatite 


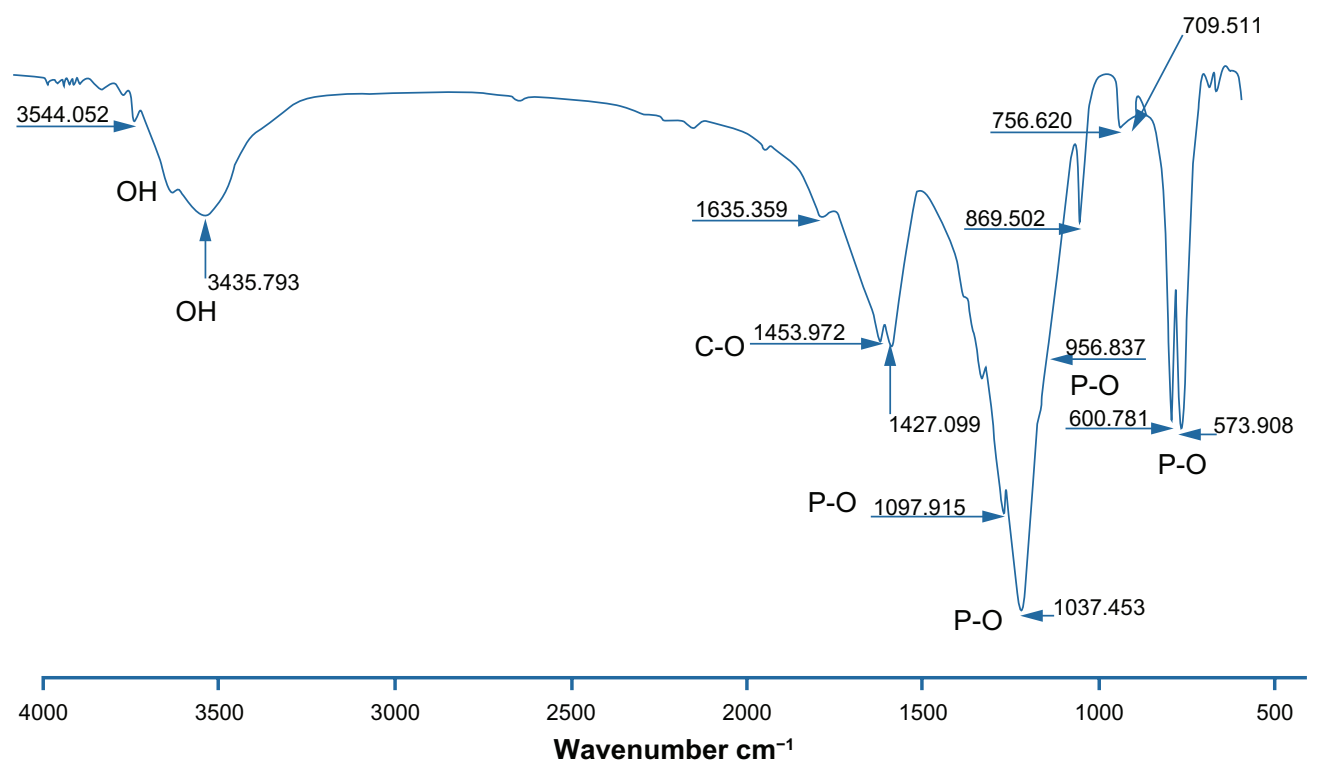

Figure 2 Fourier transform infrared spectroscopy of the heat-treated powder at $550^{\circ} \mathrm{C}$.

powder. Van der Houwen et al also present carbonate ions in a band of 873-1456 $\mathrm{cm}^{-1}$ related to dissolving $\mathrm{CO}_{2}{ }^{15}$

\section{XRD analysis}

The XRD pattern of heat-treated powder at $550^{\circ} \mathrm{C}$ is shown in Figure 3. Peaks related to hydroxyapatite are indicated in the range of $2 \theta=25-35$. Based on this spectrum, two-phase hydroxyapatite and fluorapatite are presented in the sample.

Based on XRD, the presence of a tetra calcium phosphate phase is not observed. The value of this phase in the thermodynamic conditions for the mixing ratio $\mathrm{Ca}: \mathrm{P}=1: 72$ is theoretically about $40 \%$. A change in the chemical ratio of the sol-gel process with different combinations of calcium phosphate led to the predicted phase based on equilibrium curves, which are not the same as other researchers have found. ${ }^{16}$ Particle size is detected by the Scherer equation: ${ }^{13}$

$$
D=K \lambda / B_{1 / 2} \operatorname{Cos} \theta
$$

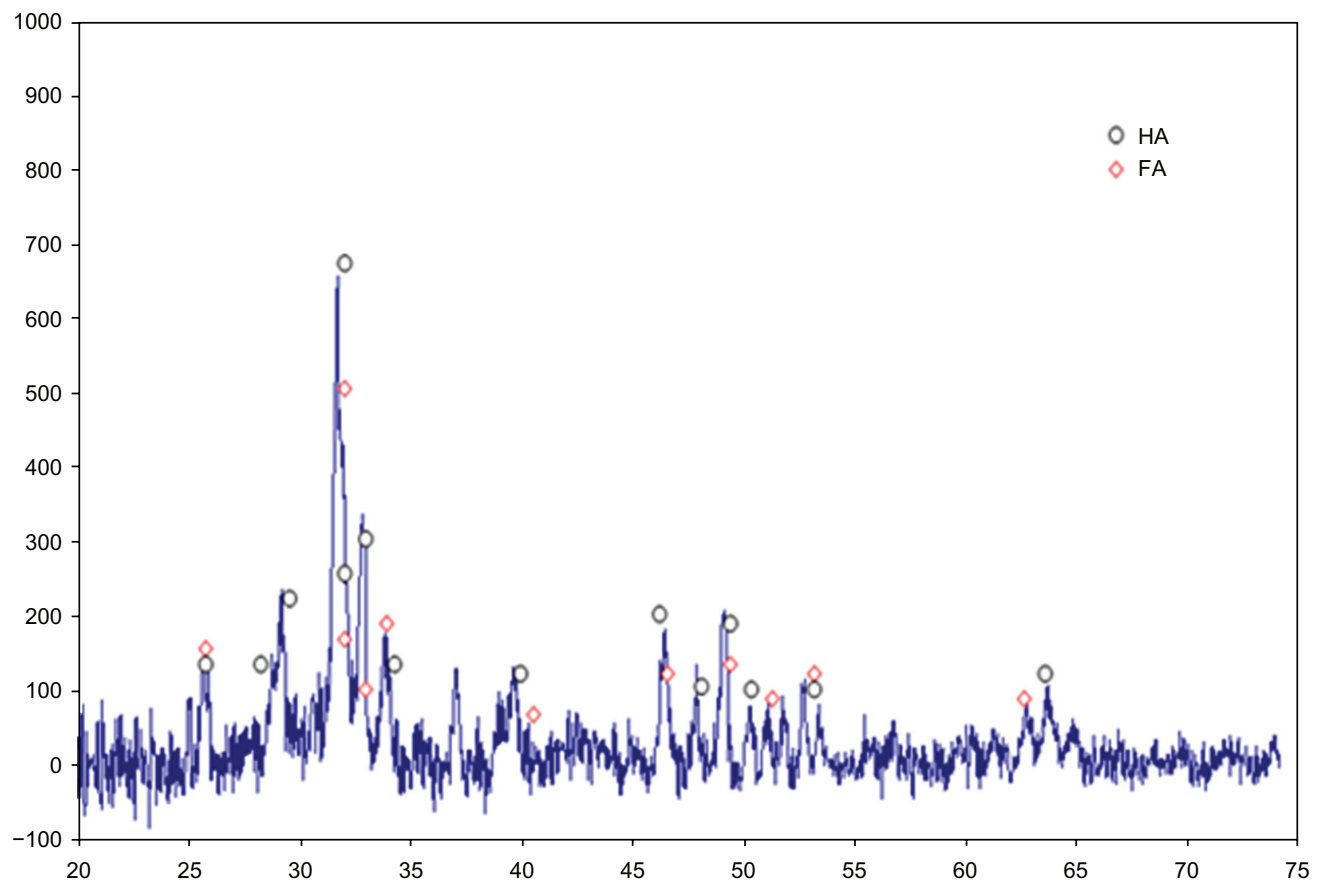

Figure $3 \mathrm{X}$-ray diffraction curves of powder after heat treatment at $550^{\circ} \mathrm{C}$. 
In Equation $1, D$ is particle size $\left(\mathrm{A}^{\circ}\right), K$ is $0.9, \lambda$ is the wavelength of $\mathrm{X}$-rays against $1.54056 \mathrm{~A}^{\circ}, \lambda$ is Bragg angle of peak from diffraction, and $B_{1 / 2}$ is in terms of radians.

$$
B_{1 / 2}=\left(B_{m}{ }^{2}-b_{s}^{2}\right)
$$

Based on Equation 1, two (Scherer) particles of about $20 \mathrm{~nm}$ were obtained. Crystallinity degree of samples was calculated from Equation 3:13

$$
X_{c}=1-\left(V_{112 / 300}-I_{300}\right)
$$

Crystallinity degree of samples obtained was about $70 \%$.

\section{Microscopic analysis}

SEM images of powders with different magnifications (4000X and 10,000X) are shown in Figure 5. Spherical particles formed in this temperature showed particle sizes to be about $100 \mathrm{~nm}$ and very homogeneous. Considering the SEM image, it seems that the agglomerates were sufficiently dispersed in the Zetasizer testing conditions. The Zetasizer experiments for the dispersed particles in its own conditions showed particle sizes with an average size of $100 \mathrm{~nm}$ (Figure 4).

Electron transmission microscopy images and diffraction patterns of powder samples are shown in Figure 6. TEM images show particle size to be about $100 \mathrm{~nm}$, which conforms to Zetasizer patterns.

\section{Cellular analysis}

For cytotoxicity investigations, cells cultured in the presence of samples were observed after 72 hours under an inverted

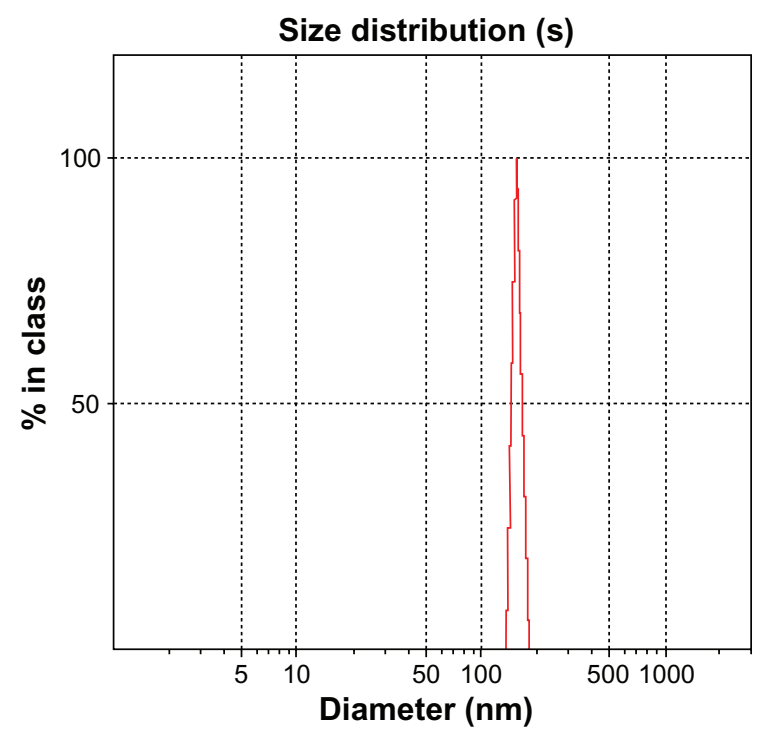

Figure 4 Particle size distribution of two-phase fluorapatite-hydroxyapatite powder at $550^{\circ} \mathrm{C}$.
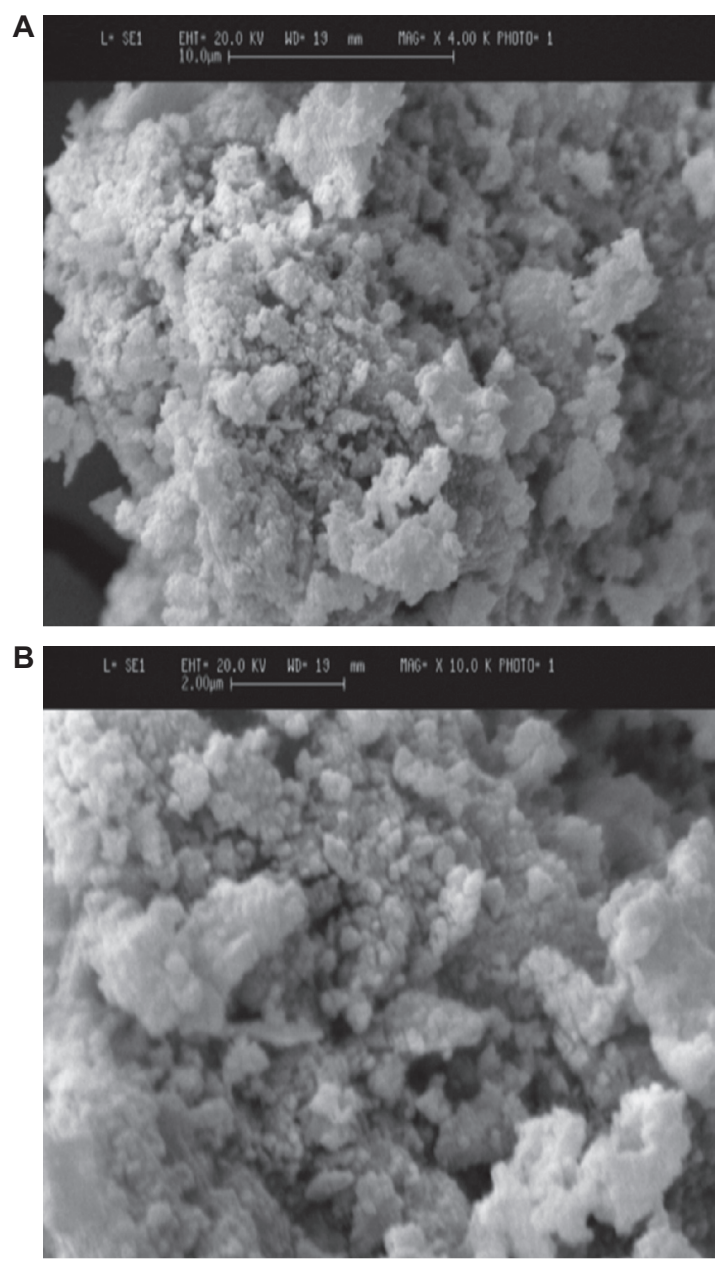

Figure 5 Scanning electron microscopy images of fluorapatite-hydroxyapatite nanoparticles (5A: 4000X; 5B:10,000X).

microscope (Nikon TS-100 Model 200X). Figure 7 shows cell growth on the control (TCPS) surface and nanopowders. Figure 7A shows the growth of the fibroblast cells on the control Petri dish with good cellular growth and adhesion at $37^{\circ} \mathrm{C}$. Figure $7 \mathrm{~B}$ shows cellular growth with nanopowders. The nanopowder sample has good growth that is almost comparable with the control sample.

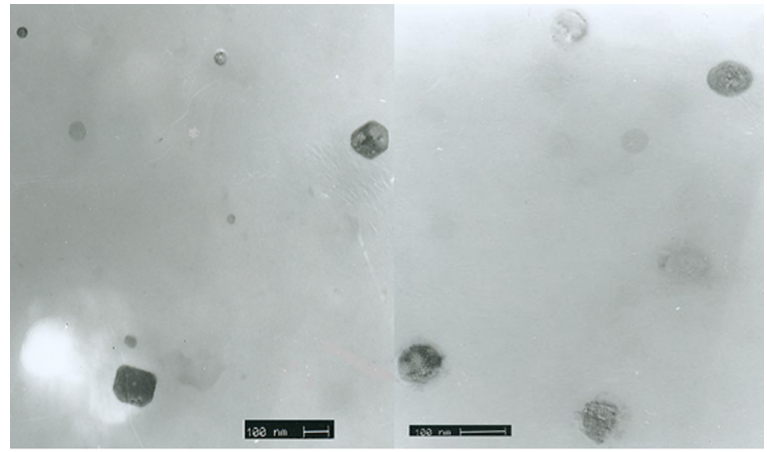

Figure 6 Transmission electron microscopy shows nanoparticles with regular shapes. 

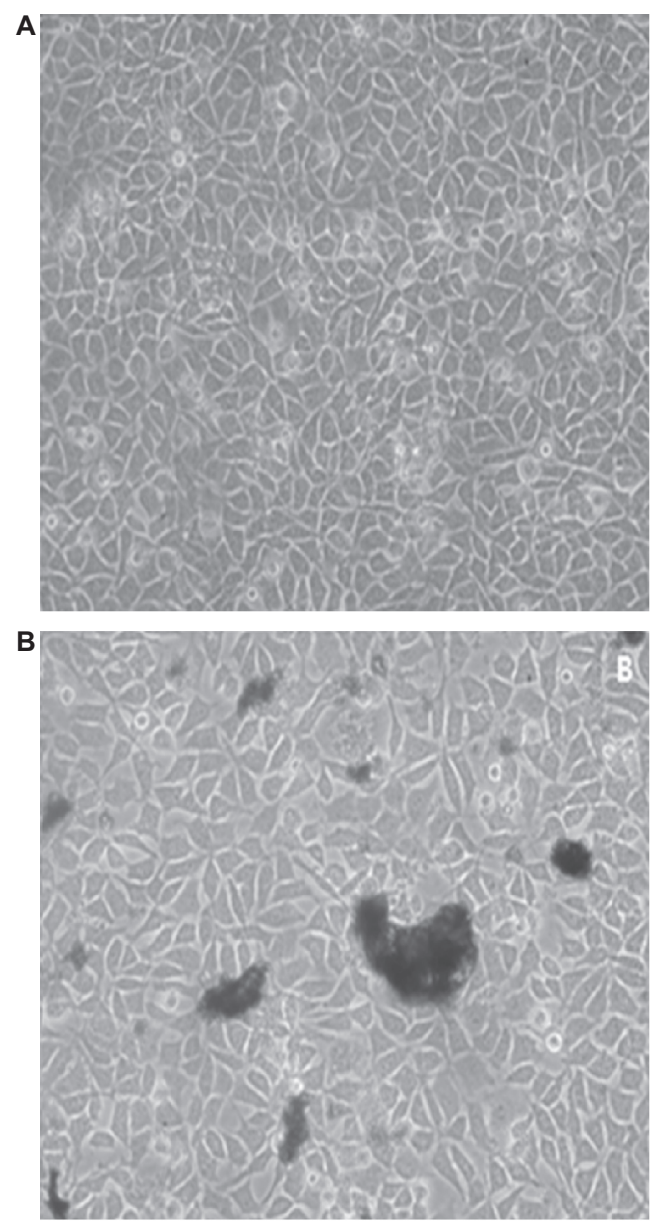

Figure 7 Optical microscopic images of cells cultured in the presence of control samples (sample (A) containing the powder (B)).

\section{Conclusion}

In this study, the powder sample of the fluorapatitehydroxyapatite nanocomposite was synthesized with a $\mathrm{Ca}: \mathrm{P}$ ratio of $1: 72$.

FTIR analysis revealed that the nanocomposite was slightly carbonated. The crystallinity of the hydroxyapatite component estimated by XRD was found to be about $70 \%$. Very fine distribution of the nanosized fluorapatite-hydroxyapatite grains, as well as the calcium-deficient hydroxyapatite agglomerates, was identified in the SEM studies. XRD-based estimation revealed the crystallite sizes to be about $20 \mathrm{~nm}$. The Zetasizer experiments for the dispersed particles in its own conditions showed an average size of $100 \mathrm{~nm}$. SEM and TEM analysis showed particle size to be about $100 \mathrm{~nm}$, which conforms to Zetasizer patterns. The results of cellular investigation show the positive effect of nanopowders on the cells. Cellular studies show nontoxicity of nanoparticles compared with the control sample. These powders can be used as a scaffold for bone and teeth.

\section{Disclosure}

The authors report no conflicts of interest in this work

\section{References}

1. Cengiz B, Gokce Y, Yildiz N, et al. Synthesis and characterization of hydroxyapatite nanoparticles. Colloids and Surfaces A: Physicochemical and Engineering Aspects. 2008;322(1-3):29-33.

2. Larsen MJ, Jensen SJ. Solubility, unit cell dimensions and crystallinity of fluoridated human dental enamel. Arch Oral Biol. 1989;34(12): 969-973.

3. Finkelstein MJ, Nancollas GH. Trace fluoride and its role in enamel mineralization. J Biomed Mater Res. 1980;14(4):533-535.

4. Legeros RZ, Silverstone LM, Daculsi G, Kerebel LM. In vitro carieslike lesion formation F-containing tooth enamel. J Dent Res. 1985;62: $138-144$.

5. Shackelford J. Bioceramics (Advanced Ceramics). New Jersey, USA: Prentice Hall; 1992.

6. Kim S, Kumta PN. Sol-gel synthesis and characterization of nanostructured hydroxyapatite powder. Mater Sci Eng B. 2004;111:232-236.

7. Liu D-M, Yang Q, Troczynski T, Tseng Wenjea J. Structural evolution of sol-gel derived hydroxyapatite. Biomaterials. 2002;23:1679-1687.

8. Jones FH. Teeth and bones: applications of surface science to dental materials and related biomaterials. Surf Sci Reports. 2001;42(3-5): 75-205.

9. Sanosh KP, Chu M-C, Balakrishnan A, et al. Synthesis of nano hydroxyapatite powder that simulate teeth particle morphology and composition. Curr Appl Phys. 2009;9(6):1459-1462.

10. Li H, Huang W, Zhang Y, Zhong M. Biomimetic synthesis of enamellike hydroxyapatite on self-assembled monolayers. Mater Sci Eng C. 2007;(27):756-761.

11. Chatzistavrou X, Esteve D, Hatzistavrou E, et al. Sol-gel based fabrication of novel glass-ceramics and composites for dental applications. Mater Sci Eng C. 2010;30(5):730-739.

12. Nikčević I, Jokanović V, Mitrić M, et al. Mechanochemical synthesis of nanostructured fluorapatite/fluorhydroxyapatite and carbonated fluorapatite/fluorhydroxyapatite. J Solid State Chem. 2004;177(7): 2565-2574.

13. Cullity BD. Elements of X-ray Diffraction. 2nd ed. Morris Cohen, editor. Reading, MA: Addison-Wesley Publishing; 1977.

14. Suchanek W, Yoshimura M. Processing and properties of hydroxyapatitebased biomaterials for use as hard tissue replacement implants. J Mater Res. 1998;13(1):94-117.

15. Van der Houwen JAM, Cressey G, Cressy BA, Valsami-Jones E. The effect of organic ligands on the crystallinity of calcium phosphate. J Cryst Growth. 2003;249(3-4):572-583.

16. Chirantha Prageeth R. Synthesis and Characterization of Strontium Fluorapatite [thesis]. Las Vegas, NV: University of Nevada; 2005.
International Journal of Nanomedicine

\section{Publish your work in this journal}

The International Journal of Nanomedicine is an international, peerreviewed journal focusing on the application of nanotechnology in diagnostics, therapeutics, and drug delivery systems throughou the biomedical field. This journal is indexed on PubMed Central,

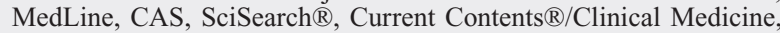

\section{Dovepress}

Journal Citation Reports/Science Edition, EMBase, Scopus and the Elsevier Bibliographic databases. The manuscript management system is completely online and includes a very quick and fair peer-review system, which is all easy to use. Visit http://www.dovepress.com/ testimonials.php to read real quotes from published authors. 